\title{
Gathering the Big Picture: Healthcare Issues Survey, Year Three
}

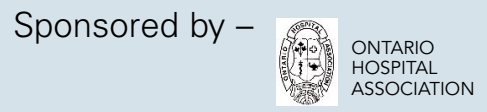

\author{
Quspital
}

The third annual Healthcare Issues Survey was conducted during the Ontario Hospital Association Conference in November 2001. Undertaken with the joint sponsorship of Hospital Quarterly, Philips and the $\mathrm{OHA}$, the Survey asked conference participants to rank the issues that are most critical in their organizations. Close to 600 conference delegates participated, a significant increase over the 414 participants in last year's survey.

Those who responded ....

The composition of the respondents remained consistent with previous years, with delegates from community hospitals supplying $52 \%$ of responses. Hospitals with operating budgets of less than $\$ 50$-million dominated the responses $-38 \%$ of the total. The largest single group by profession were clinical managers (16\%) followed by other medical professionals (10\%), board members (9\%), IT professionals (7\%) and nurses (7\%).

\section{Organization Type (2001)}

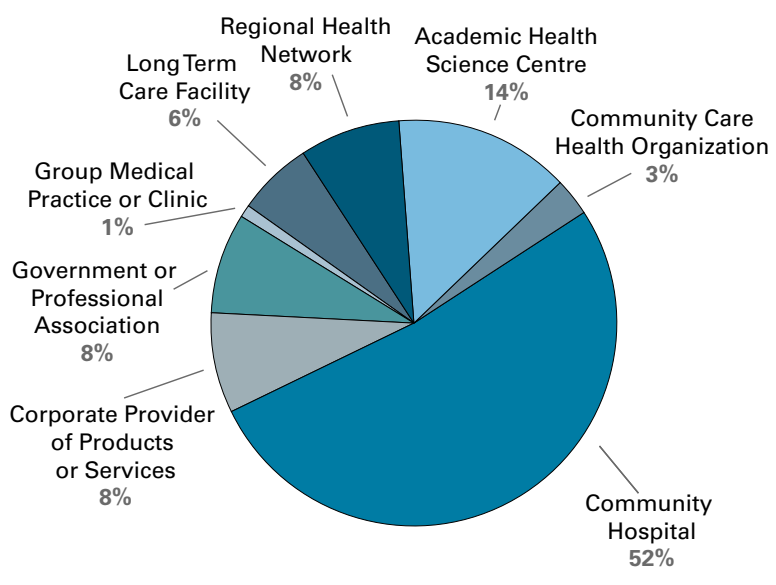

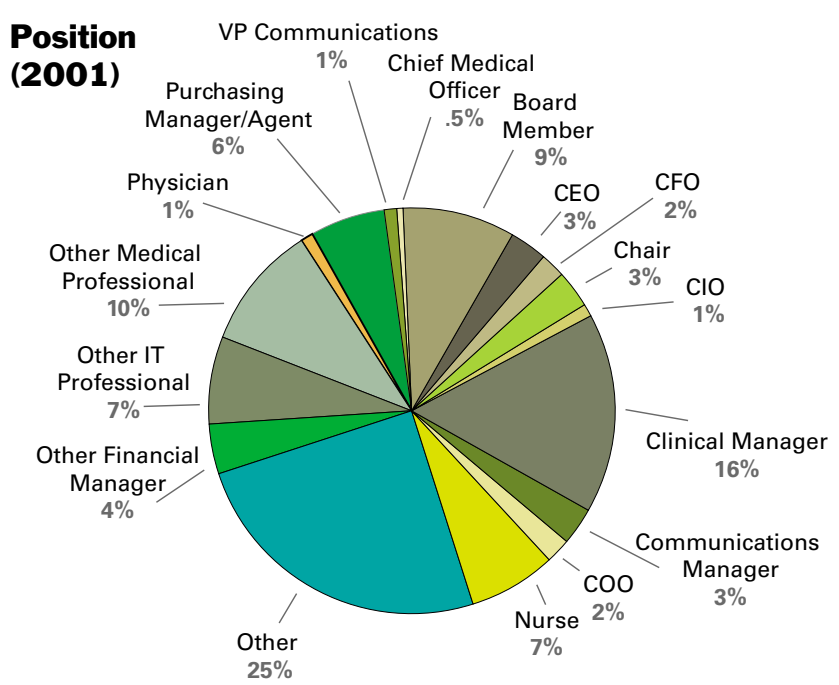

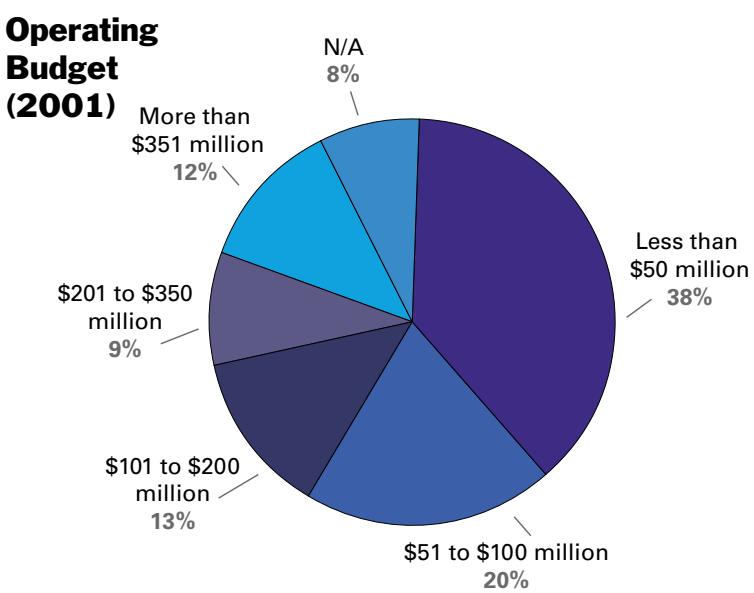

For the first time, participants were asked to identify the most significant challenge they face in their work. The three top responses from the 323 delegates who answered were: funding and financial resources (26\%), staffing (14\%) and workload (9\%). 


\section{Importance of Factors in Managing} Healthcare Environment

Asked about the importance of various factors in managing their healthcare environment, "pressures on costs" emerged as the most commonly cited issue. This was followed by the "increasing demands of the aging population" and the "need to communicate with other professionals."

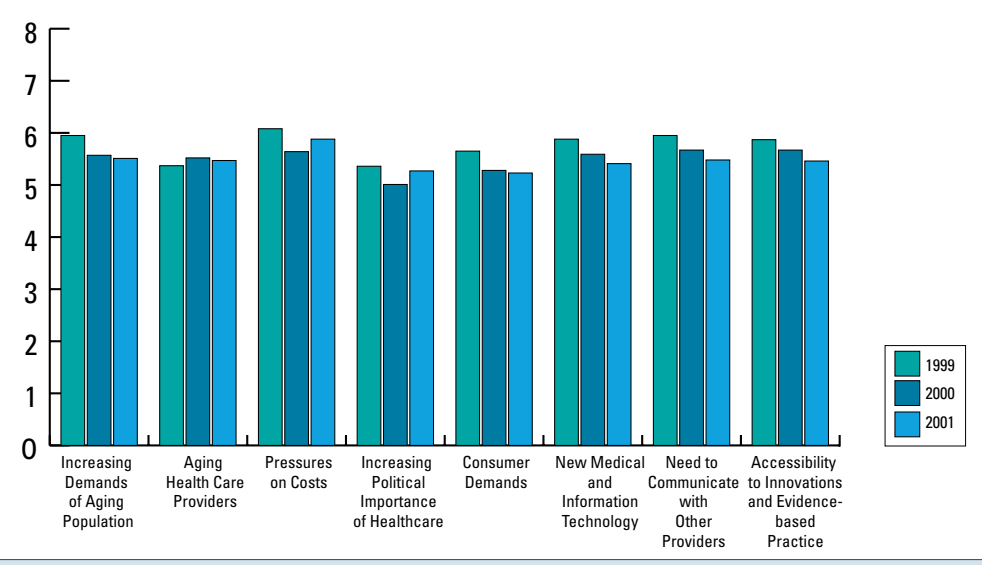

\section{Expectation of the Impact of IT Applications}

A question about the expectation of the impact of information technology applications on their organization, found that most believed "Intranets/extranets" would have the strongest impact, followed by "data mining tools" and "decision tools."
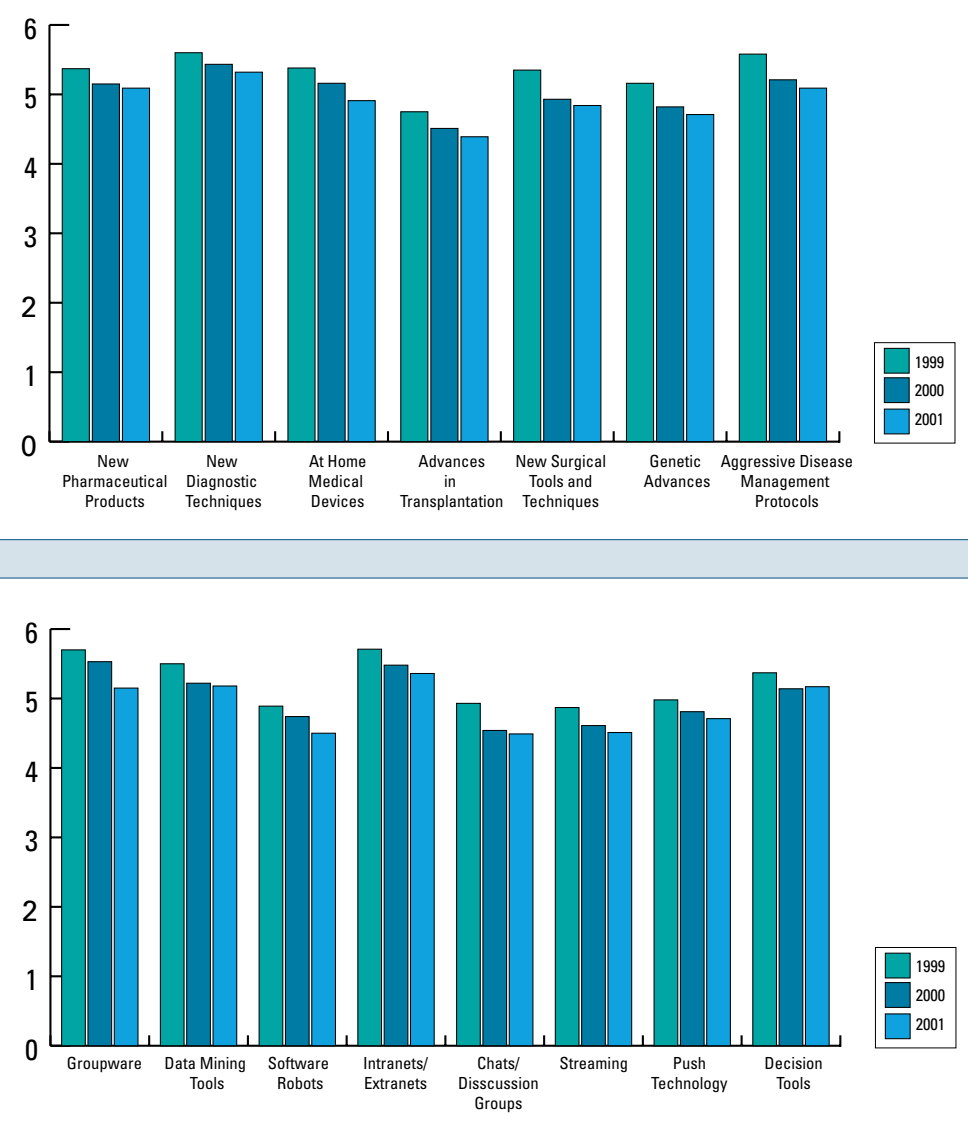

\section{Learning Method About New Technology}

Asked about how they learned about new technologies, the most commonly indicated method was the "Internet" followed by "continuing education programs" and "conferences

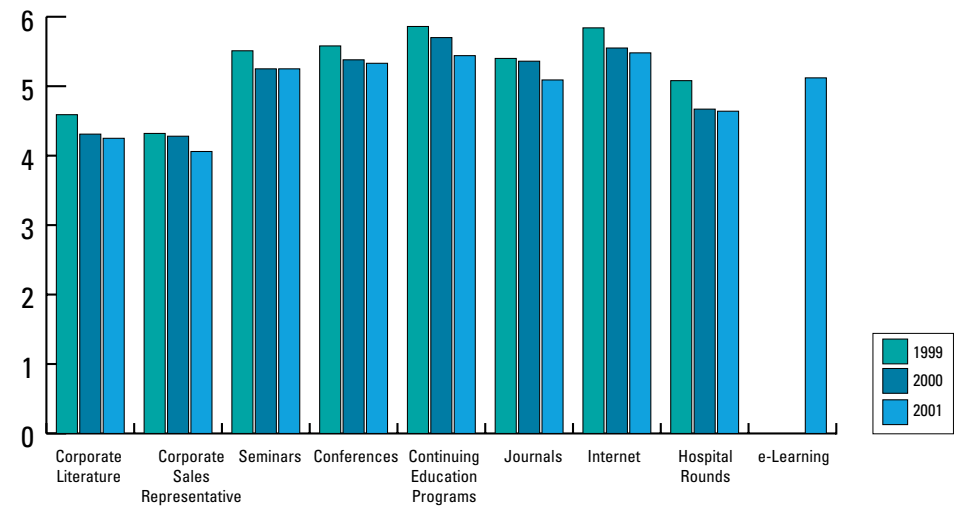


Minister Clement responds to the media scrum while OHA President, David Mackinnon (right rear) and in-coming Chair of the OHA Board of Directors Leo Stevens, President of the William Osler Health Centre (left rear) look on.

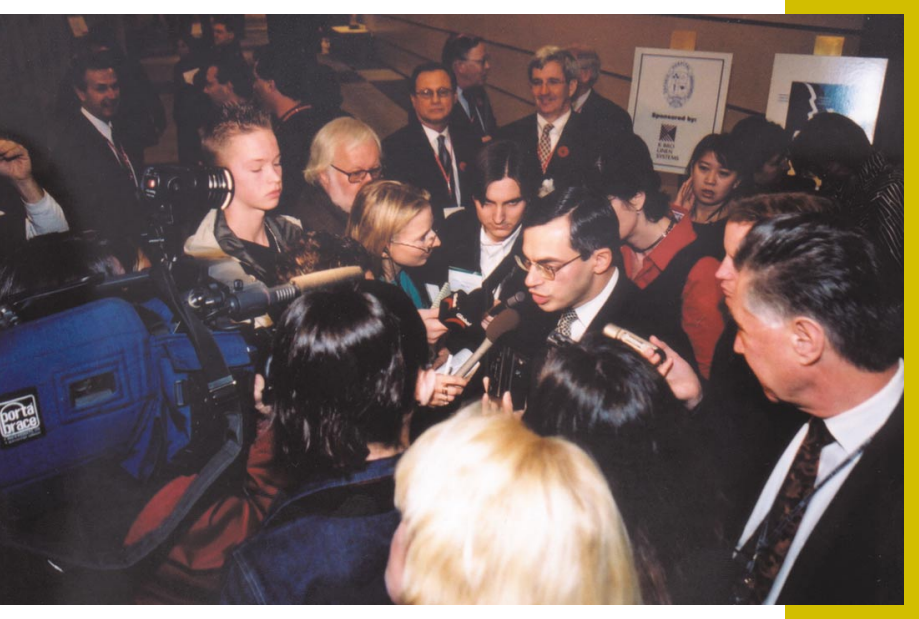

November 5, 6 \& 7, 2001

Metro Toronto Convention Centre - Toronto, Ontario, Canada

Thousands gathered in Toronto this past November at the 77th Annual Ontario Hospital Association (OHA) Convention \& Exhibition. An incredible networking opportunity, the event brought together over 7,000 participants to share information and best practices in healthcare.

The convention featured more than 70 educational sessions, 300 speakers and a trade show of $270+$ exhibitors. Featured keynote speakers this year included best-selling authors, Thomas Homer-Dixon (The Ingenuity Gap), John Naisbitt (High Tech/High Touch: Technology and our Search for Meaning), and Lance Secretan (Reclaiming Higher Ground: Creating Organizations that Inspire the Soul), consumer-advocate, Ralph Nader, and former politicians, Marc Lalonde and Bob Rae. Delegates were also able to preview the latest in healthcare products and services on the exhibition floor - including special sections devoted to IT at Silicon Alley, environmentally responsible health care at Green Lane and innovations in health system management at the National Best Practices Display.

Take advantage of the opportunity to learn from leading experts in the healthcare field at the 2002 OHA Convention \& Exhibition on November 18 - 20 at the Metro Toronto Convention Centre. For more detailed information, visit www.oha.com.

With more than 300 speakers and 270+ exhibitors, the annual OHA Convention is the largest healthcare show of its kind in North America. 



\section{Green Health Care Awards}

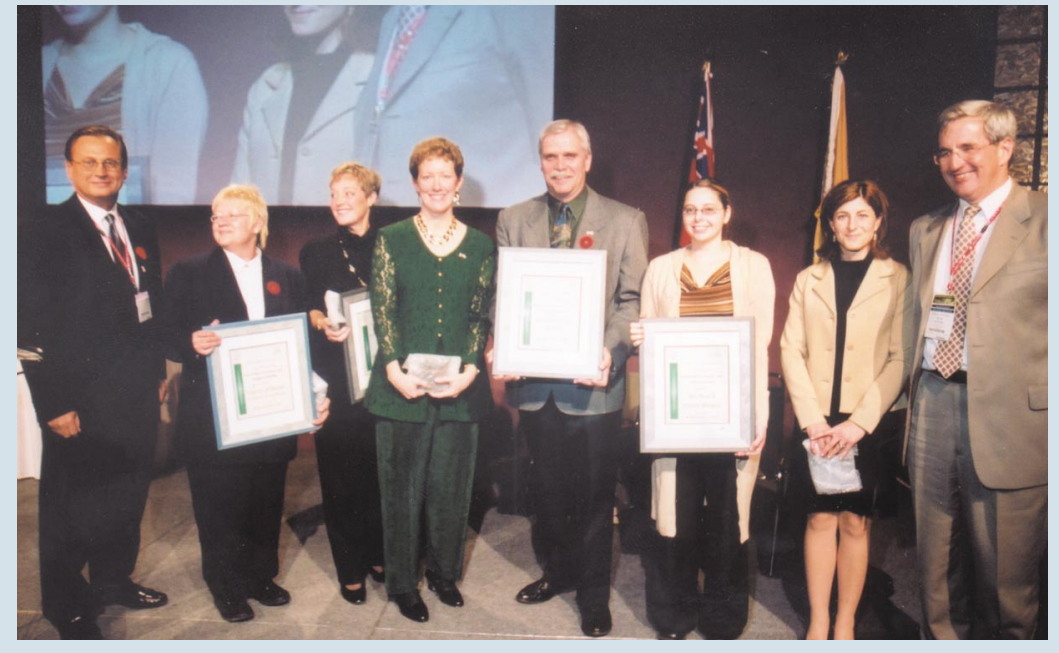

- L-R: Leo Stevens, Chair OHA Board of Directors, Valerie O'Grady (HSC), Helen Wright (CMH), Joanne Kiefer (Norfolk General), J.J Knott (Norfolk Gen), Shannon-Melissa Dunlop (St. Mary's Hospital), Lydia Chudleigh (St. Mary's Hospital) and OHA CEO David MacKinnon.
The Ontario Hospital Association and the Canadian Coalition for Green Health Care presented the first annual Green Health Care Awards in recognition of leadership and excellence in reducing healthcare's environmental impact.

Energy Conservation

Norfolk General Hospital

Pollution Prevention

St. Mary's General Hospital

Overall Leadership

Cambridge Memorial Hospital

Individual Leadership

Valerie O'Grady

The Hospital For Sick Children

\section{The Ted Freedman}

\section{Innovation in Education Award}

The inaugural Ted Freedman Innovation in Education Award went to The Ottawa Hospital, K.O.A.L.A. TM Development

Team: Dr. Michael Fung Kee Fung, Dr. Karen Fung Kee

Fung, Dr. Mark Walker, Sergio Miguel and Chantal Lacasse, in recognition of the development and provision of the "K.O.A.L.A. ${ }^{\text {TM }}$ Computerized Obstetrics and Gynaecology Automated Learning Analysis" tool. From left: Drs. Michael and Karen Fung Kee Fung accept the award from Mr. Freedman.
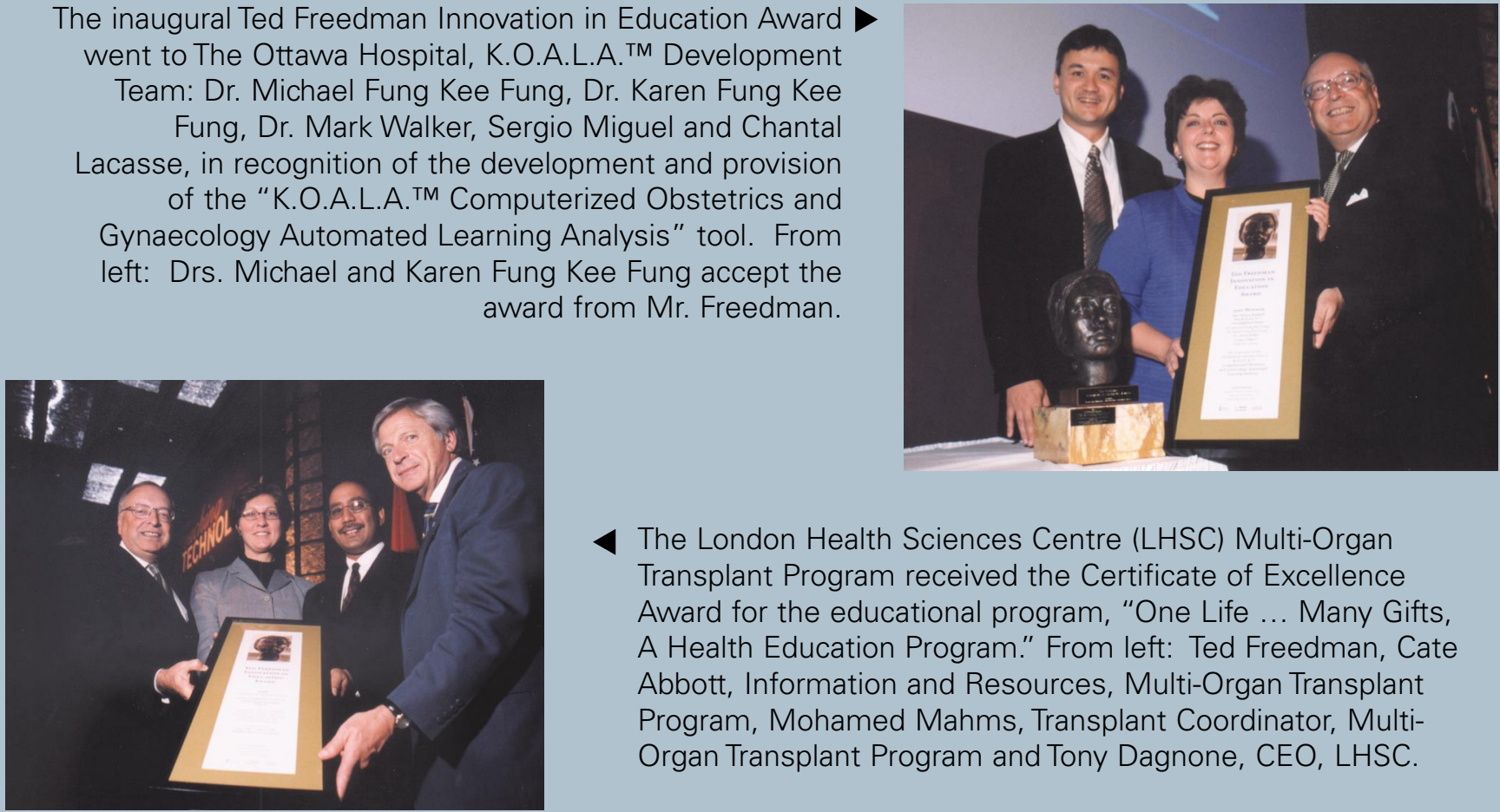

The London Health Sciences Centre (LHSC) Multi-Organ Transplant Program received the Certificate of Excellence Award for the educational program, "One Life ... Many Gifts, A Health Education Program." From left: Ted Freedman, Cate Abbott, Information and Resources, Multi-Organ Transplant Program, Mohamed Mahms, Transplant Coordinator, MultiOrgan Transplant Program and Tony Dagnone, CEO, LHSC. 
And the winners are...

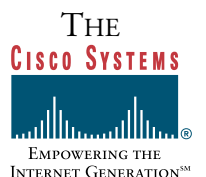

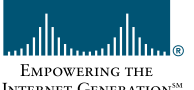

National Best Practices Award is presented to

Leamington District Memorial Hospital

Recipient of The Best Of THE

National Best Practices Award

$$
\begin{gathered}
\text { THE } \\
\frac{\text { Ortho-Clinical Diagnostics }}{\text { agohmon-fochmon company }}
\end{gathered}
$$

National Best Practices Award

is presented to

Hamilton Emergency Services Network

\section{THE $m$ \\ mediSolution}

National Best Practices Award

is presented to

Norfolk General Hospital

THE
PRODUITS MÉDICAUX
fohnson a fohmuson
MEDICAL PRODUCTS

National Best Practices Award

is presented to

Trillium Health Centre

\section{THE \\ ․ ARAMARK \\ HEALTHCARE SUPPORT SERVICES}

National Best Practices Award

is presented to

Toronto Grace Hospital

\section{THE \\ (5) PHILIPS \\ Let's make things better.}

National Best PRACTICES Award

is presented to

University Health Network

\section{THE \\ ThP HEWLETT}

National Best PRACTICES AWARD

is presented to

Chatham-Kent Health Alliance

\section{THE}

\section{COMPAQ}

Inspiration Technology

National Best Practices Award

is presented to

St. Joseph's Healthcare Hamilton -

Centre for Evaluative Medicines

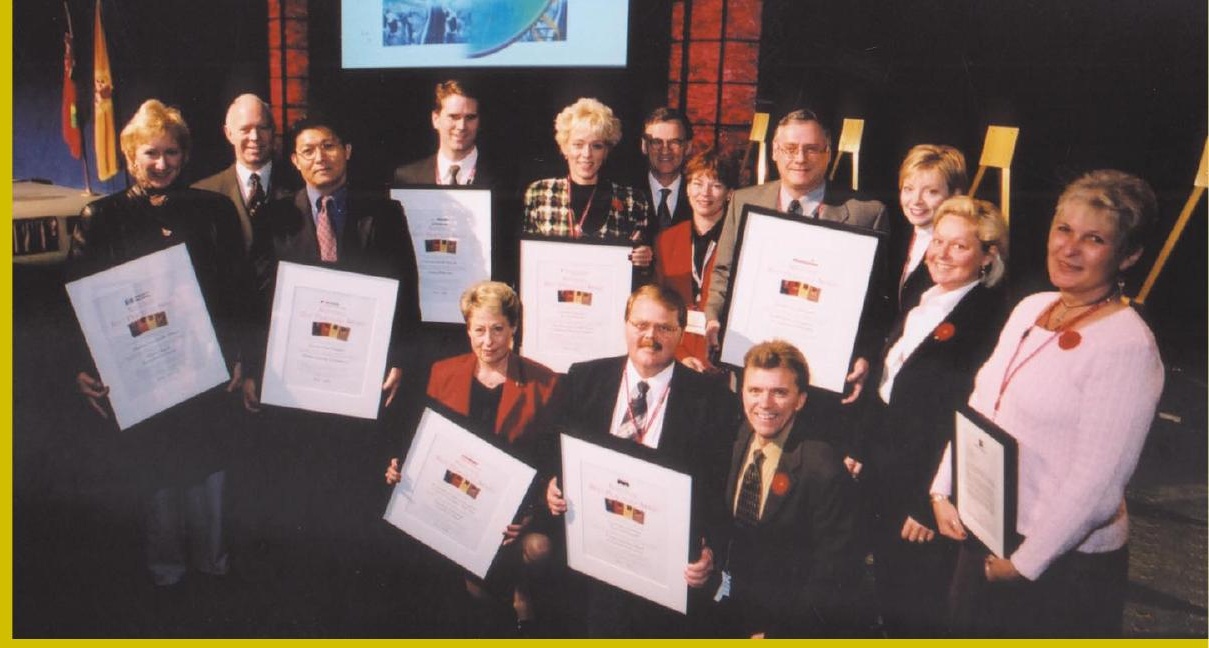

\section{National Best Practices}

Corporate representatives making the Best Practices Awards include: Sharon McDonald of Aramark Canada, Anne Lawrence of Compaq, Bob Miller of Hewlett Packard, Steve Lawrence of Cisco Systems, Anton Hart, our publisher, and Mary Lapaine, Chair Elect of the Ontario Hospital Association.

Best Practices award winners were represented by: Roberta Ament and Warren Chant, Leamington District Memorial Hospital; Winton Cape, Toronto Grace Hospital; Jocelyn Garrett, St. Joseph's Healthcare; Greg Lewis, University Health Network; Cathy MacDowell, Hamilton Emergency Services Network; Linda Vansco, Norfolk General Hospital; and Sharon Pfaff, Chatham-Kent Health Alliance.

The sponsors extend their sincere appreciation to the judges of the National Best Practices Awards: Sarah Downey, Director of Corporate Planning, University Health Network and Hy Eliasoph, Senior Manager, Deloitte \& Touche.
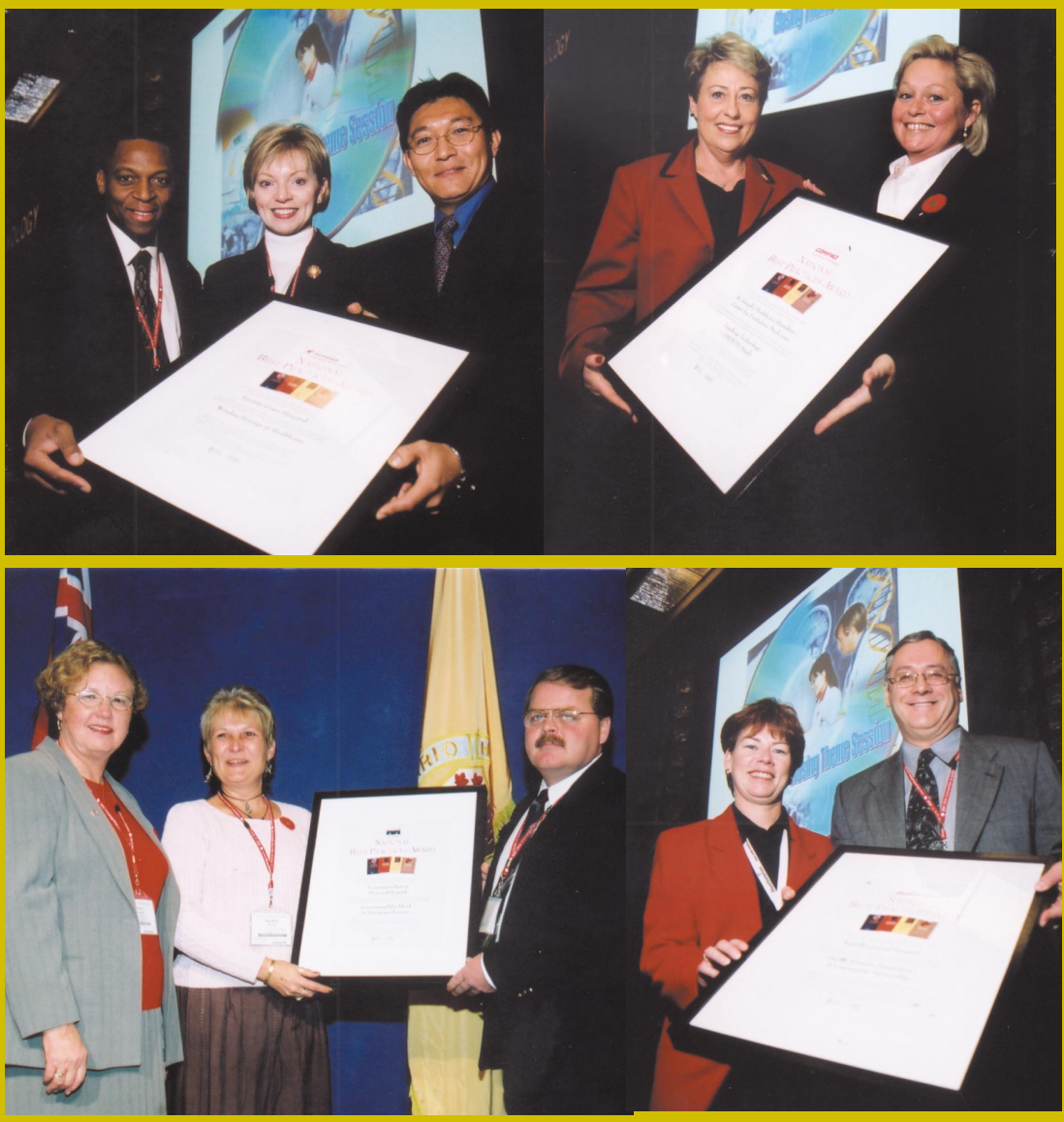

Hospital Quarterly Winter 2001/2002 
3M Canada Company

Abbott Laboratories

Acart

Acclaim-SBA Disability Management Inc.

Adcom Videoconferencing

Aladdin Temp-Rite Canada

ALARIS Medical Systems

American College of Healthcare Exec

AMTELCO 1Call Healthcare

AQSR Canada, Inc.

Arbell Inc.

Arjo Canada Inc.

Assistive Devices Program Ministry

of Health and Long-Term Care

Austco Marketing \& Service Canada

Avaya Canada Corp.

Aventis Pasteur

B D

B D O Dunwoody LLP

B. Braun Medical Inc.

Banzai Corporation Pvt. Ltd.

Barefoot Science Inc.

Barrie Communications Equipment

Limited

Barrier Free Lifts (Canada)

Baxter Corporation

Bell Canada

Bidinoff Marketing Inc.

Bio Nuclear Diagnostics

Bolton Dental Manufacturing

Booth Centennial Healthcare Linen

Services

Borden Ladner Gervais LLP

Britech Information Systems Ltd.

British Consulate - General

C.D. Sonter Management Inc.

Cactus Health Systems

Call24 Wireless Callbox Systems

Cambridge Memorial Hospital

Campana Systems Inc.

Canadian Centre for Pollution Prevention

Canadian Coalition for Green

Health Care

Canadian College of Health Service Executives

Canadian Coordinating Office for

Health Technology Assessment (CCOHTA)

Canadian General Standards Board

Canadian Health Marketplace

Canadian Health Services Research

Foundation

Canadian Healthcare Association

Canadian Healthcare Manager

Canadian Hearing Society

Canadian Institute for Health

Information

Canadian Parking Equipment Ltd.

Care Plus

Carecor Health Services Ltd.

Carr McLean/Montel

Carroll Healthcare

Carsen Group Inc.

Cassels Brock \& Blackwell LLP

Centura Floor \& Wall Fashions

Chatham-Kent Health Alliance

Children's Choice Learning Centers, Inc.

Chubb Security Systems

$\mathrm{CIBC}$ and VeriSign

Cisco Systems Canada Co.

City of Toronto - Water and

Wastewater

Clarica

ClinSaver Software Inc.

$\mathrm{COACH}$ - Canada's Health Informatics
Association

Cogent Environmental Solutions

Cogient Corporation

College of Nurses of Ontario

Compass Flooring Ltd.

Compugen Services Ltd.

Continuum Solutions

Crescendo Systems Corporation

Cummins Ontario Inc.

Customer Service Excellence

Corporation

D.L.G.L. Ltd.

Dainolite Ltd.

Dairy Farmers of Canada

Deloitte \& Touche LLP

Delta Marketing

Dictaphone Canada

DigiDyne Inc.

Dukane Canada

Dynamed Health Care Systems

e k 3 Technologies Inc.

Enbridge Consumers Gas

Encom Information Systems Inc.

Environment Canada

Erinoak

EVACUSLED INC.

Family Communications

FHS - Focus on Health \& Safety Inc.

First Products Inc.

Fitch Surveillance Systems Inc.

Fluorescent Lamp Recyclers Inc.

Fraser Milner Casgrain LLP

Freudenberg Canada

FrontRange Solutions Inc.

FutureLink Canada

G \& K Work Wear Corporation of Canada

G E Medical Systems

G R A S P Systems Ltd.

GEM Health Care System

Girit Canada

Global Healthcare Exchange

Global Medical Products

Globe And Mail

Green Shield Canada

Grey Bruce Health Services

H A S Solutions

HT V Systems Ltd. \& Zenith

Electronics Corporation

Hamilton Area Hospitals \& McMaster

University

Health Canada

Health Care Health \& Safety

Association of Ontario

Healthcare Furnishings Inc.

Healthcor Inc.

HealthLink Clinical Data Network

HealthPRO Procurement Services

Healthtech Inc.

HealthyConnect

Herman Miller for Healthcare

Hewlett Packard (Canada) Ltd.

Hicks Morley Hamilton Stewart

Storie, LLP

Hill-Rom Canada

HIREHealthcare

Hospital Information Services (Canada)

Hospitality Network

Hospitals In-Common Laboratory Inc.

IDenticam Systems

IMS Maxims Inc.

Innofocus

Institute for Clinical Evaluative

Sciences (ICES)

Interface Canada

Interhealth Recruitment Corporation
Investors Group

$|R|$ Consultants to Management

Johnsonite

Jones Packaging Inc.

Killdara Corporation

Lanier Canada Inc.

Lason

Lexmark Canada Inc.

LMS Medical Systems

Loki Management Systems Inc.

London Health Sciences Centre

M D S Inc.

M. C. Healthcare Products

MacDougall, MacDougall \& MacTier

Mannington Commercial

Marsh Canada Limited

Maxivox Inc

MCCS Ltd.

McDavis Sales \& Service Ltd.

McKesson HBOC

MED2020 Health Care Software Inc

Med-Emerg International Inc.

Medfall Inc.

MedHunters.com

mediate.calm

Medical Action Industries

Medical Mart Supplies Ltd.

Medical Placement International

Medical Systems Management

Medical Waste Management Inc.

Medi-Man Rehabilitation Products

Medirex Systems Inc.

MediSolution Ltd

MEDITECH (Medical Information

Technology, Inc.)

Med-Tech Environmental Ltd.

MERX - Cebra Inc.

Metropolitan Wire (Canada)

MHA Program - University of Ottawa

Microcell Solutions Inc. (Fido)

Microlites Scientific

Micromedex

Miller Thomson LLP

Ministry of Health and Long-Term Care MIP

Mitel Networks

Momentum Healthware

Morneau Sobeco

Mother Parker's Tea \& Coffee Inc.

Multitone Wireless (Canada)

National Systems Company

National Therapy Products Inc.

NEC Canada Inc.

Nicholby's Gift Shop

Nor-Am Patient Care Products Ltd.

NORDX/CDT, Inc.

Northeastern Ontario Medical

Education Corporation

NRCAN/Office of Energy Efficiency

Nursing \& Homemakers Inc

Omni Floorcoverings Ltd.

Omnicell

Ontario Women's Health Council

Organ Donation Ontario

Ormed Information Systems Ltd.

O-Two Systems International Inc.

P C L Constructors Canada Inc.

Pacs to Macs Best of Breed Solution

Paging Network of Canada

Panorama Business Views

Perfect Development Co., Ltd.

Pfizer Canada

Philips Speech Processing

Propper Manufacturing Co., Inc.

Prosec Protection Systems Inc.

Purkinje Inc.

Pyxis Healthcare Systems

Quinte Healthcare Corporation

Rauland-Borg (Canada) Inc.

Registered Nurses Association of Ontario

Rogers AT\&T - Uptown

Communications

S.R.T. Med-Staff

Saint Elizabeth Health Care

Save \& Give

SCA North America

Scott Paper Limited

Secure Care Products, Inc.

Serve-Canada Food Equipment Limited

Servicemaster - Clinical Engineering Solutions

Siemens Health Solutions

Sierra Systems Group Inc.

Signature Group Inc.

SimplexGrinnell

Six Continents Hotels

Sodexho

Softcare Innovations Inc.

Source Medical Corporation

Spacesaver Corporation

Spectrum Health Care

St. Joseph's Health Care, London

St. Michael's Hospital

Stanley Access Tech.

Steelcase

Stryker Bertec Medical Inc.

Summerberry Products

Sunrise Medical Canada Inc.

Symbol Technologies Canada, Ulc.

Tanita Corporation of America Inc.

c/o McArthur Medical Sales Inc.

Techlem Medical Corporation

Tektone Sound \& Signal Mfg., Inc.

Tel-e Connect Systems Ltd.

Telus National Systems

Tempus Software, Inc.

The HIROC Group

The Mackie Group - Health Care

Relocations \& Logistics

The Statum Group

The Stevens Company Limited

The Toronto Board of Trade

Tim Hortons (The TDL Group Ltd.)

Toronto Medical Laboratories

Toronto Police Service, Parking

Enforcement, Disabled Liaison Unit

Total Care Technologies Inc.

Tricific Enterprises Inc.

Trillium Health Care

trios Training Centres/trios Support

Services

Unisource Canada Inc.

University Health Network

Versus Technology Inc.

VHA Home Healthcare

Victorian Order of Nurses (VON)

Vitality Food Service Canada 